\title{
RP and the Cameroon English Accent: An Overview
}

\author{
Jean-Paul Kouega \\ University of Yaounde I, Yaounde, Cameroon
}

\begin{abstract}
This paper examines the acrolectal variety of L2 (Second Language) English in Cameroon (CamE for short), with a view to identifying its characteristic segmental features. The setting of the research is Cameroon, a Central African country sharing borders with Nigeria, Chad, and the Central African Republic. In this country, English and French are joint official languages, with the Anglophone community following the English educational system and the Francophone community the French educational system. The focus of the study is on the English of Anglophone speakers. The data, which were collected through recordings, are produced by highly educated users of CamE (teachers, medical doctors, journalists, etc.), and the reference model used for the analysis is RP (Received Pronunciation) English, which is the model adopted for education in the country. The framework of analysis is mainly structural, though insight from the generative approach is occasionally used to explain some generalisations. The findings reveal that the L2 English accent in Cameroon exhibits a dominant feature known as spelling pronunciation. English words tend to be pronounced as their orthography suggests, which causes such word pairs as tree/three, bet/birth, was/worse, etc., to be homophonous. Consonant clusters tend to be simplified while vowel lengthening tends not to be observed. As central vowels are hardly realized, peripheral vowels tend to occur more frequently than they do in native accents. This way of speaking, which is being transmitted intergenerationally through education, is so widespread that efforts to change it are doomed to fail.
\end{abstract}

Keywords: Cameroon English, spelling pronunciation, consonant, vowel, sound cluster

\section{Introduction}

This study sets out to describe the characteristic segmental features of the English spoken by highly educated users in Cameroon, a Central African country where French and English share official status. The informants, whose speech was recorded while they were doing their ordinary everyday work, are such acrolectal speakers as teachers, lawyers, medical doctors, and journalists, i.e., people who have successfully gone through the Cameroon system of education and who occupy high-ranking positions in professional life and are therefore looked up to by the mass of less educated people. The work is divided into three sections, with the first discussing English in education in Cameroon; the second describing the vocalic system of Cameroon English in relation to RP (Received Pronunciation), the reference model adopted in the country; and the third looking into the consonantal system of this variety of English. These are considered in turn.

Jean-Paul Kouega, professor, Department of English, University of Yaounde I. 


\section{English in Education in Cameroon}

Formal education in English was introduced in pre-independence British Cameroons (henceforth Anglophone Cameroon) by a church planting team of English Baptist Missionaries led by Joseph Merrick in 1843. At independence in 1960, the part of Cameroon under French administration (henceforth Francophone Cameroon) adopted French as its official language and, therefore, as the medium of instruction in all schools. In 1961, when Francophone Cameroon federated with part of Anglophone Cameroon (see details in Kouega, 2007a), the new country adopted both French and English as its joint official languages, with French becoming a subject in Anglophone schools and English a subject in Francophone schools. Since then, two systems of education have operated in the country, namely the Francophone and the Anglophone sub-systems. The focus in this study is on the latter sub-system, a description of which is provided in a document published by the Cameroon GCE Board (General Certificate of Education Board) in 1997 and MINEDUC (Ministère de l'Education Nationale) in 2000 (for a discussion of the Francophone sub-system, see among other works, MINEDUC, 2001; Kouega, 2007a).

Primary education in Cameroon is offered by three types of institutions: public schools run by the state, mission schools run by Catholic and Protestant clergy, and non-ecclesiastical schools run by businessmen. At the primary school level, Anglophone pupils are taught the English language subject and all other curriculum subjects through the English medium for a period of seven years. The English language syllabus, which is devised by Government-appointed school inspectors, lays emphasis on three skills, i.e., reading, writing, and listening, with little space being devoted to pronunciation and speaking. At the end of the seventh year, Anglophone pupils sit for the FSLC (First School Leaving Certificate).

At the secondary school level, which also lasts for seven years, Anglophone pupils are taught in the English medium, a variety of subjects including accounting, biology, chemistry, commerce, and economics, to name only these few. In addition, they are taught the English language subject in the first five years of secondary education. At the end of the fifth year, i.e., in Form Five, they sit for the GCE O' Level (General Certificate of Education, Ordinary Level). It is required that, of all the subjects taught in class, candidates should choose not less than six, which may or may not include English. The syllabus of the English language subject, for those who choose to take it, comprises three papers. These are listening comprehension (Paper 1, 25 minutes), composition (Paper 2, 60 minutes), and writing (Paper 3, two hours and 15 minutes). In the listening comprehension test, a passage of about 400 words is read aloud by a teacher and the candidates' comprehension of this passage is checked in their answers to the multiple choice questions based on it. As can be inferred from this description, the candidates' own spoken performance is not evaluated. Two observations can be made here. First, one can obtain the GCE O' Level without taking the English language subject. Second, even those candidates who take the English language subject can pass it with a very low proficiency in the speaking skill, as this skill is not evaluated.

The next two years of secondary education are devoted to the reinforcement of knowledge in the subjects chosen by the learners. At this level, the English language disappears from the curriculum, as it is assumed that the learners are already competent in English; the nearest subject which is retained is English literature, whose component parts include drama, prose, and poetry. At the end of secondary education, candidates sit for the GCE A' Level (General Certificate of Education, Advanced Level). They are allowed to take up to five subjects from a list of 14 curriculum subjects. The chosen five, as can be guessed, may or may not include English literature. In 
short, at the secondary level, very little place is devoted to the English language subject, and within this subject, very little place is devoted to pronunciation and speaking. This is likely to have a devastating effect on secondary learners' spoken performance.

At tertiary level, students take different directions according to their chosen subjects: science-oriented students register in science faculties while arts-oriented students go to arts, law, or economics faculties (for language problems faced by Anglophone students at tertiary level in Cameroon, see among other works, Kouega, 1999a, 2007a, 2008). In short, the English language syllabus prepares the ground for learners' low performance in the spoken English skill in general and in accuracy in speaking in particular. Features of the segmental level of their speech are dealt with in the next two sections.

\section{Vocalic Features}

Under the heading "Vocalic Features" are grouped the common processes involving English vowels in the speech of the informants. The analysis takes up monophthongs, diphthongs, triphthongs, and the dominant phonological processes that underlie the realization of vowels in Cameroon English. These are considered in turn below.

\section{Monophthongs}

RP English comprises 12 monophthongs which can be grouped according to various parameters including tongue height, tongue area raised, and lip rounding. One relevant parameter for this study is vowel length, which groups these monophthongs into short and long vowels.

Long vowels. Vowel length is hardly realized in the variety of English spoken in Cameroon. The five long $\mathrm{RP}$ vowels /i, a, $, \mathrm{u}, 3 /$ are systematically replaced by a number of short vowels. For example, the vowel /3/ is usually replaced by $/ \varepsilon, \%$. This can be illustrated with the following words in Table 1 , where the target orthographic segments are underlined.

Table 1

Realization of the Long Vowel /3/

\begin{tabular}{|c|c|c|c|c|}
\hline RP vowel & \begin{tabular}{|l|} 
CamE (English in \\
Cameroon) vowels \\
\end{tabular} & Illustrations & RP renderings & CamE renderings \\
\hline \multirow{12}{*}{ /3/ } & \multirow{6}{*}{ 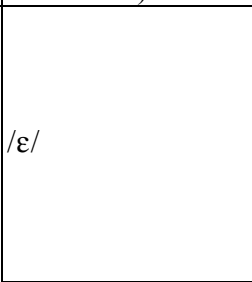 } & Early & $31 \mathrm{I}$ & eli \\
\hline & & Learn & $13 n$ & len \\
\hline & & Service & S3VIS & sevis \\
\hline & & Assert & $\partial s 3 t$ & aset \\
\hline & & Circle & s3kl & sekul \\
\hline & & Firist & f3t & fest \\
\hline & \multirow{6}{*}{$/ 2 /$} & Work & w3k & wok \\
\hline & & Worship & W3 كІр & 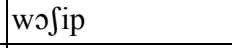 \\
\hline & & Journey & d33nI & d3oni \\
\hline & & Courteous & k3tiəs & kotios \\
\hline & & Church & $t \int 3 t \int$ & t $\int 0 t \int$ \\
\hline & & Disturbed & dist3b & distop \\
\hline
\end{tabular}

When one looks carefully at this variability, one discovers that orthography is the underlying factor; actually, spelling pronunciation is the cause of variability in Cameroon English, as most words in this variety of English 
are pronounced in a way that reflects their spelling. This explains why the orthographic segments EAR (learn), ER (serve), and IR (first) are rendered / $\varepsilon /$, and why OR (work) and OUR (journey) are rendered /o/. This same principle underlies other renderings in the variety.

The long vowel /i/ is usually pronounced in a way that is not auditorily different from its short/I/ counterpart (Mbangwana, 1987; Kouega, 1999b, 2007b). In fact, very few Cameroonians can contrast/i/ as in "seat" and/I/ as in "sit". Similarly, /a/ as in "cart" and /æ/ as in "cat", /o/ as in "port" and /p/ as in "pot", and /u/ as in "food" and $/ \mathrm{v} /$ as in "foot" are not contrasted in this variety.

Short vowels. They are usually pronounced in a way that reflects the spelling of the words in which they occur. The front vowel /I/ is replaced by /e, $\varepsilon /$ in many words including "storage" and "budget". The central vowel $/ \Lambda /$ which is never realized, is systematically replaced by $/ 0 /$ as in the words "such" and "money" and by /au/ in a few words like "country". The central vowel /o/ is rare and therefore has the most complex renderings in Cameroon English. Depending on the spelling of the words in which it occurs, it is pronounced /i, $\varepsilon$, a, o, u, ia/ as the words "flexible", "document", “attend", "labour", "today", and "parliament" in Table 2 show.

Table 2

Realization of the Short Vowels /I/, / / , and /o/

\begin{tabular}{|c|c|c|c|c|}
\hline RP vowels & CamE vowels & Illustrations & RP renderings & CamE renderings \\
\hline \multirow{2}{*}{ /I/ } & $/ \mathrm{e} /$ & Storage & storid3 & storet \\
\hline & $/ \varepsilon /$ & Budgẹt & $\mathrm{b} \wedge \mathrm{d} 3 \mathrm{It}$ & bodzet \\
\hline \multirow{2}{*}{$/ \Lambda /$} & $/ 2 /$ & Such & $s \Lambda t \int$ & sots \\
\hline & $/ \mathrm{au} /$ & Country & $\mathrm{k} \Lambda \mathrm{ntrI}$ & kauntri \\
\hline \multirow{6}{*}{ /ə/ } & $/ \mathrm{i} /$ & Flexible & fleksəbl & flegzibul \\
\hline & $/ \varepsilon /$ & Document & dpkjumənt & dokument \\
\hline & $/ \mathrm{a} /$ & Attend & otend & atend \\
\hline & $/ \mathrm{J} /$ & Labour & leibo & lebo \\
\hline & $/ \mathrm{u} /$ & Today & tədeI & tude \\
\hline & $/ \mathrm{ia} /$ & Parliament & paləmənt & paliament \\
\hline
\end{tabular}

In short, the 12 RP monophthongs are represented by a total of 7 monophthongs, which are: /i, e, $\varepsilon, a, o, ~ \supset, ~ u /$ as found in such words as "sit", "storage", "budget", "attend", "gon", "labour", and "today", where the target segments are underlined.

\section{Diphthongs}

The English language is credited with eight diphthongs which can be grouped into three categories according to the target vowels towards which they glide. These target vowels are /I, U, ə/. As these vowels are hardly realized in Cameroon English, so too are their corresponding diphthongs. The diphthong /eI/ is replaced by /e, a/ as in "eight" and "fatal". The diphthongs /aI/ and /or/ are usually rendered /ai/ as in "time" and /oi/ as in "toy", which are very close to the RP renderings. The diphthongs /ov/ and /au/ behave differently: While /ov/ is systematically replaced by /o/ as in "poll" and /o/ as in "go", /av/ is usually realized /au/ as in "found". The diphthongs /Іə, عə, və/ are never realized, for an obvious reason: The target monophthong/ə/ is rare in Cameroon English. Depending on the spelling of a given word, the diphthong /ı/ may be realized /ie, ia, io, $\varepsilon /$ as in the words "near", "malaria", "opinion", and "inherent". As for /عə/ and /və/, they are usually monophthongised into $/ \varepsilon /$ as in "chairman" and /o/ as in "ensure" (see Table 3 ). 
Table 3

Realization of RP Diphthongs

\begin{tabular}{|c|c|c|c|c|}
\hline RP vowels & CamE vowels & Illustrations & RP renderings & CamE renderings \\
\hline \multirow{2}{*}{ /eI/ } & $/ \mathrm{e} /$ & Eight & eIt & et \\
\hline & $/ \mathrm{a} /$ & Fatal & fertl & fatal \\
\hline /aI/ & /ai/ & Time & taim & taim \\
\hline$/ \mathrm{OI} /$ & $/ \mathrm{oi} /$ & Toy & toI & toi \\
\hline$/ \mathrm{au} /$ & $/ \mathrm{au} /$ & Found & faund & faund \\
\hline \multirow{2}{*}{ /əo/ } & $/ 2 /$ & Poll & pəul & pol \\
\hline & $/ \mathrm{o} /$ & Go & gəu & go \\
\hline \multirow{4}{*}{ /ІІа/ } & $\mid$ ic/ & Near & กІว & nic \\
\hline & /ia/ & Malaria & məleərıə & maleria \\
\hline & /ij/ & Opinion & әрınıən & opinion \\
\hline & $/ \varepsilon /$ & Inherent & Inhiərənt & inherent \\
\hline /عə/ & $/ \varepsilon /$ & Chairman & $\mathrm{t} \int \varepsilon ə \mathrm{~m} ə \mathrm{n}$ & $\mathrm{t} \int \varepsilon \mathrm{man}$ \\
\hline$/$ /บə/ & $/ \mathrm{s} /$ & Ensure & In $\int$ Uว & En $\int 0$ \\
\hline
\end{tabular}

Spelling pronunciation has converted certain digraphs into a number of unproductive diphthongs including /ie/ as in "dossier", /ij/ as in "studio", /iu/ as in "Mauritius", /ui/ as in "fluid", /ue/ as in "graduate", /uع/ as in "cruel", /ua/ as in "mortuary", and /uo/ as in "superfluous". These are illustrated in Table 4.

Table 4

New Diphthongs in CamE

\begin{tabular}{|c|c|c|c|c|}
\hline Orthographic segments & CamE rendering & Illustrations & RP renderings & CamE renderings \\
\hline ie & $/$ ie/ & Dossier & 'dpsier & 'dosie \\
\hline io & /ij/ & Studio & 'stjudiəu & 'studio \\
\hline $\mathrm{iu}$ & /iu/ & Mauritius & 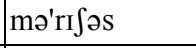 & mo'rifius \\
\hline ui & /ui/ & Fluid & 'fluid & 'fluit \\
\hline ua & /ue/ & Graduate & 'græd3uət & gra'dzuet \\
\hline ua & /ua/ & Mortuary & 'motfərI & 'motfuari \\
\hline ue & $/ \mathrm{u} \varepsilon /$ & Cruel & kruəl & 'kruel \\
\hline uo & $/ \mathrm{uo} /$ & Superfluous & su'p3fluəs & su'pefluos \\
\hline
\end{tabular}

In short, the eight RP diphthongs are either replaced by the five monophthongs /e, $\varepsilon, \mathrm{a}, \mathrm{o}, \mathrm{o} /$ or represented by a total of 13 diphthongs, of which three are RP-sounding diphthongs, i.e., /ai, au, oi/ and 10 are new

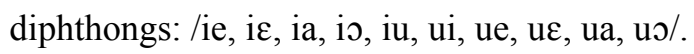

\section{Triphthongs}

These vowels, as O'Connor (1973) noted, are characterised by the fact that they comprise "sequences of three vocalic segments functioning as a single phoneme" (p. 22). Symbolically, a triphthong may be regarded as a VVV structure functioning as a single phoneme. In Cameroon English, triphthongs are never realized; while the initial and final $\mathrm{V}$ elements remain vowels, the central $\mathrm{V}$ element is always realized as a consonant, giving triphthongs a VCV structure. This central C element is usually a glide, either /j/ or /w/, as Table 5 shows.

A close look at the realizations of the various vowels listed in Table 5 reveals that there are many phonological processes underlying these renderings. The dominant process is spelling pronunciation, as can be 
inferred from the analysis above; most processes which are common in native Englishes such as vowel reduction, trisyllabic laxing, CiV tensing, and pre-R breaking (Chomsky \& Halle, 1968), to name only these few, tend not to occur in Cameroon English, as will be shown below.

Table 5

Realization of RP Thriphthongs in CamE

\begin{tabular}{|c|c|c|c|c|}
\hline RP vowels & CamE vowels & Illustrations & RP renderings & CamE renderings \\
\hline /егә/ & /eja/ & Player & pleıә & 'pleja \\
\hline /агә/ & /aja/ & Desire & dı'zaıə & di'zaja \\
\hline /агә/ & $/ a j \varepsilon /$ & Diet & daiət & 'dajet \\
\hline /агә/ & /ajo/ & Riot & raiət & 'rajot \\
\hline /ОІә/ & /oja/ & Employer & Im'рləэə & im'ploja \\
\hline /avə/ & /awa/ & Sour & savə & 'sawa \\
\hline /əuə/ & /owa/ & Lower & ləuə & 'lowa \\
\hline
\end{tabular}

Spelling pronunciation is a process whereby words are pronounced the way their spelling suggests. It results from various factors, including what Simo Bobda (1994) called inadequate learning of reading rules by early teachers. Actually, successive batches of students imitate their teachers and in turn serve as models for future batches of students. As a result, the same patterns of speech are transmitted intergenerationally. For example, the following words, where the targeted segments are underlined, are - and have always been — pronounced as they are spelt, as these transcriptions in Table 6 show.

Table 6

Spelling Pronunciation in CamE

\begin{tabular}{|c|c|c|}
\hline Words & RP & CamE \\
\hline About & o'baut & a'baut \\
\hline Catherine & 'kæOrın & kate'rain \\
\hline Circuit & 's3kit & 'sckwit \\
\hline Cleanse & klenz & klins \\
\hline Colonel & 'k3nl & kolo'nel \\
\hline Country & 'kuntrI & 'kauntri \\
\hline Fatal & 'fertl & 'fatal \\
\hline Forehead & 'fprid & 'fohet \\
\hline Haiti & 'heItI & 'haiti \\
\hline Indigestion & 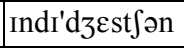 & indai'd $z \varepsilon \int$ Son $^{2}$ \\
\hline Infinite & 'Infinit & in'fainait \\
\hline Legal & 'ligəl & 'ligal \\
\hline Martyr & 'matə & 'mataja \\
\hline Parliament & 'paləmənt & 'paliament \\
\hline Plait & plæt & plet \\
\hline Primordial & praI'mədiəl & pri'modial \\
\hline Southern & 'sıðən & 'sauden \\
\hline Tear (v) & teə & tie \\
\hline Tomb & tum & tom \\
\hline Vehement & 'viəmənt & ve'hement \\
\hline Vehicle & 'virkl & 'vehikul \\
\hline
\end{tabular}


Another effect of spelling pronunciation is the reduction of the number of syllables contained in some words and the increase of the number of syllables contained in others. This can be illustrated by the following words in Table 7 . Table 7

Syllabification in CamE

\begin{tabular}{|l|l|l|}
\hline Words & RP & CamE \\
\hline Evening & 'Ivnı & 'ivinin \\
\hline Liberalise & 'librəlaız & libera'lais \\
\hline Wednesday & 'wenzdI & we'nesde \\
\hline Apocope & ə'ppkəpı & apo'kəp \\
\hline Mayor & meə & 'mej \\
\hline Annihilate & ə'narəleIt & anihi'let \\
\hline General & 'dzenrəl & 'dzeneral \\
\hline Martyr & 'matə & ma'taja \\
\hline
\end{tabular}

Vowel reduction in native Englishes replaces a peripheral vowel or a potential diphthong by the weak vowel /a/ and occasionally/I/. This can be illustrated by the word "doctor" whose unstressed syllable takes /a/. This weak vowel being rare in CamE as was indicated above, it is evident that the process fails to take place in this variety, as Table 8 shows.

Table 8

Realisation of RP Weak Vowels in CamE

\begin{tabular}{|c|c|c|}
\hline Words & RP & CamE \\
\hline Doctor & 'doktə & 'dokto \\
\hline Accident & 'æksıdənt & 'aksident \\
\hline Status & 'steitəs & 'stetius \\
\hline Mortuary & 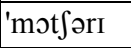 & 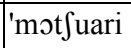 \\
\hline Similar & 'simılə & 'simila \\
\hline Special & 'spefl & 'spefial \\
\hline
\end{tabular}

Trisyllabic laxing converts a tense vowel occurring in a word into a lax vowel in the derivative of this word. Put in simple terms, it laxes vowels in antepenultimate position. This can be illustrated by the verb "compile" and its derivative "compilation", where the diphthong /ai/ in the stem "compile" is laxed into /I/ in the derivative "compilation". Similar stem-derivative pairs include "obscene-obscenity", "severe-severity", "derive-derivation", "insane-insanity", and "declare-declaration". In Cameroon English, laxing never takes place and, as a result, the derivatives are systematically pronounced with a tense vowel, as Table 9 shows.

Table 9

Tensing of RP Lax Vowels in CamE

\begin{tabular}{|c|c|c|}
\hline Words & RP & CamE \\
\hline Compilation & kəmpı'leIsn & 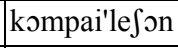 \\
\hline Declaration & deklə'rer $\int \mathrm{n}$ & 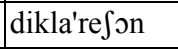 \\
\hline Derivation & derr'verJn & dirai'vefon \\
\hline Insanity & In'sænətI & in'seniti \\
\hline Obscenity & əb'senətI & ob'siniti \\
\hline Severity & SI'verətI & si'vieriti \\
\hline
\end{tabular}


$\mathrm{CiV}$ tensing converts a lax vowel occurring in a stem into a tense vowel in its derivative, especially when this derivative contains a suffix beginning with letters like -ia (acacia, Arabian, radiant), -ious (contagious, precarious), etc.. In Cameroon English, tensing never takes place, as shown in Table 10.

Table 10

Laxing of RP Tense Vowels

\begin{tabular}{|l|l|l|}
\hline Words & RP & CamE \\
\hline Acacia & ə'keI $\int ə$ & aka'sia \\
\hline Arabian & ə'reIbıən & ara'bian \\
\hline Radiance & 'reIdıəns & 'redians \\
\hline Contagious & kən'teIdzəs & kən'tedzios \\
\hline Precarious & prI'keərıəs & 'prikarios \\
\hline
\end{tabular}

Pre-R breaking inserts the weak vowel /a/ before /r/ and a preceding non-low, long vowel (Simo Bobda, 1994), therefore converting this vowel into a diphthong or triphthong. As the vowel/o/ is hardly realized in CamE, it is evident that this process is rare in this variety, as Table 11 shows.

Table 11

Laxing of RP Tense Vowels in Contexts Involving / $r$ /

\begin{tabular}{|c|c|c|}
\hline Words & $\mathrm{RP}$ & CamE \\
\hline Sarah & 'scərə & sa'ra \\
\hline Mary & 'meərI & me'ri \\
\hline Parent & 'peərənt & 'perent \\
\hline Period & 'pıərıəd & 'piriot \\
\hline Bacteria & bæk'tiərıə & bak'tiria \\
\hline Inherent & In'hıərənt & 'inherent \\
\hline Insure & 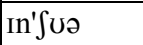 & in'so \\
\hline
\end{tabular}

In sum, the rendering of vowels in RP and CamE exhibits a number of differences, and these different renderings have influenced this non-native variety considerably. One of the visible effects is that many English homophones like "their" and "there" are pronounced differently, while many English words pronounced differently like "tear" (n, water from the eyes) and "tear" (v, cut into pieces) have become new homophones in CamE. This can be illustrated by the following examples inTable 12 .

Table 12

Homophones in RP and CamE

\begin{tabular}{|c|c|c|}
\hline Words & RP & CamE \\
\hline Tear (n) & tio & tic \\
\hline Tear (v) & teo & tic \\
\hline Their & ðعә & dia \\
\hline There & ðعə & $\mathrm{d} \varepsilon$ \\
\hline
\end{tabular}

\section{Consonantal Features}

The heading "Consonantal Feature" is grouped the processes involving English consonants in the speech of the informants. The analysis takes up voicing, clustering, and spelling pronunciation. These are considered in turn below. 


\section{Voicing}

English consonants are grouped according to the activities that take place in the glottis into two broad categories, i.e., voiced consonants like /b, d, g/ and voiceless consonants like /p, t, k/. All RP voiced and voiceless consonants do exist in CamE, but their distribution is slightly different: Voiceless consonants are occasionally voiced while voiced consonants are occasionally devoiced.

One instance of devoicing is observed in words such as "tab", "head", and "cabbage", which end in a voiced consonant each. Such voiced consonants in final position tend to be replaced by their voiceless counterparts, as Table 13 shows.

Table 13

Devoicing of Consonants in Final Position

\begin{tabular}{|l|l|l|}
\hline Words & RP & CamE \\
\hline Tab & tæb & tap \\
\hline Lab & læb & lap \\
\hline Period & 'piərıd & 'piriot \\
\hline Head & hed & het \\
\hline Bag & bæg & bak \\
\hline Big & big & bik \\
\hline Cleanse & klenz & klins \\
\hline Tease & tiz & tis \\
\hline Village & 'vilid3 & 'vilet \\
\hline Cabbage & 'kæbid3 & 'kabet \\
\hline
\end{tabular}

This devoicing of final consonants is extended to the realizations of the -S morpheme indicating plurality (e.g., teachers, pages), possession (e.g., John's, Mary's), and the third person present tense (he gives, seems). In these contexts, the morpheme is systematically rendered /s/, as Table 14 shows.

Table 14

Realization of the S-morpheme in CamE

\begin{tabular}{|c|c|c|}
\hline Words & RP & CamE \\
\hline Teachers & 'titfoz & 'titfas \\
\hline Ministers & 'mInIstəz & 'ministas \\
\hline Pages & 'peIdzIz & 'petfis \\
\hline Judges & 'd $3 \wedge d_{3} I_{Z}$ & 'dzotfis \\
\hline John's & dzanz & dzons \\
\hline Mary's & 'meərız & 'meris \\
\hline Gives & givz & gifs \\
\hline Seems & $\operatorname{sim} z$ & sims \\
\hline
\end{tabular}

Devoicing of consonants in final position also involves the morpheme -ED indicating the participle forms of verbs (e.g., attended, believed). In these contexts, the morpheme is systematically rendered $/ t /$, as Table 15 shows. 
Table 15

Realization of the ED-morpheme in CamE

\begin{tabular}{|l|l|l|}
\hline Words & RP & CamE \\
\hline Attended & a'tendid & a'tendet \\
\hline Presided & pri'zardid & pre'saidet \\
\hline Believed & b'livd & bi'lift \\
\hline Begged & begd & bekt \\
\hline
\end{tabular}

In CamE, devoicing never occurs in initial position and it is rare in medial position. The cases identified in medial position usually involve the consonant pairs $/ \mathrm{s}, \mathrm{z} /$ and $/ \int, 3 /$. The alveolar fricative consonants $/ \mathrm{s}, \mathrm{z} /$ in medial position are occasionally mixed up, with the voiceless /s/ occurring where the voiced $/ z /$ is expected and vice versa, as these two sets in Table 16 show.

Table 16

Mixing of /s/ and /z/ in Medial Position

\begin{tabular}{|c|c|c|}
\hline Words & RP & CamE \\
\hline Cosmetics & kpz'metıks & kəs'metiks \\
\hline Husband & 'h $\Lambda$ zbənd & 'hosban \\
\hline Position & pə'zIJn & po'sifon \\
\hline Preside & prizard & prisait \\
\hline Comparison & kəm'pærısn & kom'parizon \\
\hline December & dI'sembə & di'zemba \\
\hline Missile & 'misail & 'mizail \\
\hline Nursery & 'n3sərI & 'nozeri \\
\hline
\end{tabular}

A similar situation is observed with the palato-alveolar fricative consonants $/ \int, 3 /$; very often, the voiceless $/ \mathrm{S} /$ is used where its voiced counterpart $/ 3 /$ is expected, as these examples in Table 17 show.

Table 17

Devoicing of $R P / 3 /$ in $-U$ Contexts

\begin{tabular}{|c|c|c|}
\hline Words & RP & CamE \\
\hline Casual & 'kæzuəl & 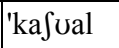 \\
\hline Closure & 'kləuzə & 'klofo \\
\hline Exposure & Iks'pəuzə & 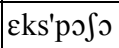 \\
\hline Leisure & 'lezo & 'lefo \\
\hline Measure & 'mezəo & 'me \\
\hline Pleasure & 'plezəo & 'plefo \\
\hline Seizure & 'sizəo & 'sifo \\
\hline Treasurer & 'trezuərə & 'tre 'ora \\
\hline
\end{tabular}

The replacement of the voiced $/ 3 /$ by the voiceless $/ S /$ is not limited to -URE words like "closure". It also involves -ION words like "decision", "division", and "television” (Simo Bobda, 1994) (see Table 18).

In sum, voicing seems to be one important factor influencing the difference in the renderings of consonants in RP and CamE. Because of this factor, many English homophones are pronounced differently while many 
English words pronounced differently have become new homophones in CamE. This can be illustrated by the following examples in Table 19.

Table 18

Devoicing of RP/3/in -ION Contexts

\begin{tabular}{|c|c|c|}
\hline Words & RP & CamE \\
\hline Decision & di'sizn & di'siðon \\
\hline Division & di'vi3n & di'viðon \\
\hline Television & 'telivizn & tele'vifon \\
\hline
\end{tabular}

Table 19

New Homophones in CamE

\begin{tabular}{|l|l|l|}
\hline Words & RP & CamE \\
\hline Lab & læb & lap \\
\hline Lap & læp & lap \\
\hline Pot & ppt & pst \\
\hline Port & pot & pot \\
\hline Potable & pptəbl & 'potabul \\
\hline Portable & 'potəbl & 'potabul \\
\hline Raise & reIz & res \\
\hline Raze & reIz & res \\
\hline
\end{tabular}

\section{Clustering}

Most RP consonant clusters are realized as expected when they occur in initial position. There are a few clusters which, in medial position, are articulated differently in the two varieties. One of them is the cluster $/ \mathrm{ks} /$, the voiced counterpart of which is /gz/, both being represented orthographically by the consonant letter -X-as in "exile" and "exam". Usually, the voiced member/gz/is used where its voiceless counterpart/ks/is expected. This can be illustrated by the following cases in Table 20 .

Table 20

Voicing of the Cluster /ks/

\begin{tabular}{|l|l|l|}
\hline Words & RP & CamE \\
\hline Exile & 'Eksail & Eg'zail \\
\hline Maximum & 'mæksıməm & 'magzimom \\
\hline Flexible & 'fleksəbl & 'flegzibul \\
\hline Exodus & 'Eksədəs & 'Egzədəs \\
\hline
\end{tabular}

Most other clusters undergo one common process, i.e., simplification. This is realized by way of deletion of the last element of a cluster or vowel epenthesis. Deletion is usually observed in contexts such as "consonant $+\mathrm{j}$ ", which can be labelled " $\mathrm{C}+\mathrm{j}$ " clusters, as in these words in Table 21.

Vowel epenthesis occurs in a number of clusters, especially clusters with syllabic $/ 1, \mathrm{n}, \mathrm{r} /$ like /fl/ in "careful", /3n/in "television" and /nr/ as "general". The epenthetic vowels which usually come into play are /i, $\mathrm{e}, \mathrm{\rho}, \mathrm{u} /$ as Table 22 shows. 
Table 21

Deletion of the Yod in RP Consonant Clusters

\begin{tabular}{|c|c|c|}
\hline Words & RP & CamE \\
\hline During & 'djuərın & 'duriy \\
\hline Annually & 'ænUəlı & 'anuali \\
\hline Executive & Ig'zekjutıV & Ek'zekutif \\
\hline Spectacular & spek'tækjulə & spe'takula \\
\hline Failure & \begin{tabular}{|l|} 
'ferljə \\
\end{tabular} & 'felio \\
\hline
\end{tabular}

Table 22

Vowel Epenthesis in CamE

\begin{tabular}{|c|c|c|c|c|}
\hline RP clusters & CamE renderings & Words & $\mathrm{RP}$ & CamE \\
\hline $\mathrm{sn}$ & zin & Basin & 'beisn & 'bezin \\
\hline $\mathrm{mn}$ & $\min$ & Gymnastics & dzım'næstık & dzimi'nastik \\
\hline br & ber & Liberalise & 'librəlaiz & libera'lais \\
\hline $\mathrm{nr}$ & ner & General & 'dzenrəl & 'dzeneral \\
\hline $\int \mathrm{n}$ & Son & Edition & I'dIJn & e'difon \\
\hline $3 n$ & Son & Division & di'vizn & di'vifon \\
\hline $\mathrm{fl}$ & ful & Careful & 'keəfl & 'keful \\
\hline $\mathrm{ml}$ & mul & Promul'gation & promlgeifn & 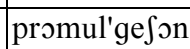 \\
\hline
\end{tabular}

\section{Spelling Pronunciation}

As noted above, this process causes words to be pronounced as they are spelt. The letters $\mathrm{TH}$ are systematically pronounced $/ \mathrm{t}, \mathrm{d} /$, with the voiceless alveolar $/ \mathrm{t} /$ replacing the voiceless interdental $/ \theta /$ and the voiced alveolar /d/ replacing the voiced interdental / $/$ in initial and medial positions. A few illustrations include the following (see Table 23).

Table 23

\section{Realization of Interdentals}

\begin{tabular}{|c|c|c|}
\hline Words & RP & CamE \\
\hline Think & $\theta \mathrm{Ink}$ & tink \\
\hline Lengthy & $\operatorname{l\varepsilon n} \theta_{\mathrm{I}}$ & lenti \\
\hline There & ðعә & $\mathrm{d} \varepsilon$ \\
\hline Together & tə'gعðə & tu'geda \\
\hline
\end{tabular}

Many other consonant letters are pronounced as their spelling suggests. This can be illustrated in Table 24 .

Similarly, many vowel letters are pronounced as their spelling suggests. This can be illustrated by the following (see Table 25).

Many sequences of letters are pronounced as their spelling suggests and, in the process, silent consonant letters are articulated (see Table 26).

Table 24

Pronunciation of Consonants Induced by Word Orthography

\begin{tabular}{|l|l|l|}
\hline Words & RP & CamE \\
\hline Fasten & fasn & fasten \\
\hline Bombing & bomin & bombin \\
\hline Stephen & stivn & stifen \\
\hline
\end{tabular}


Table 25

Pronunciation of Vowels Induced by Word Orthography

\begin{tabular}{|l|l|l|}
\hline Words & RP & CamE \\
\hline Bosom & 'buzəm & bəsəm \\
\hline Fatal & 'feitl & 'fatal \\
\hline Parliament & 'paləmənt & 'paliament \\
\hline Plait & plæt & plet \\
\hline Primordial & praI'modıəl & 'primədial \\
\hline Tomb & tum & tom \\
\hline Tortoise & 'totəs & totวis \\
\hline
\end{tabular}

Table 26

Pronunciation of Syllables Induced by Word Orthography

\begin{tabular}{|l|l|l|}
\hline Words & RP & CamE \\
\hline Colonel & 'k3nl & kolo'nel \\
\hline Vehement & 'viəmənt & ve'hement \\
\hline Forehead & 'forıd & fo'het \\
\hline Liquor & 'likə & 'likwっ \\
\hline Circuit & 's3kit & 'sikwit \\
\hline Bombing & 'bomin & 'bombin \\
\hline Singing & 'sinı & 'singin \\
\hline
\end{tabular}

In sum, spelling pronunciation seems to be an important factor contributing to the divergent renderings of consonants in RP and CamE. Because of this factor, many English homophones are pronounced differently while many English words pronounced differently have become new homophones in CamE. This can be illustrated by the following examples in Table 27.

Table 27

$R P$ and CAME Homophones

\begin{tabular}{|c|c|c|}
\hline Words & RP & CamE \\
\hline Baron & 'bærən & ba'ron \\
\hline Barren & 'bærən & 'baren \\
\hline Colonel & 'k3nl & kolo'nel \\
\hline Kernel & 'k3nl & 'kenel \\
\hline Cymbal & 'sImbəl & 'simbal \\
\hline Symbol & 'sImbəl & 'simbol \\
\hline Mare & meə & $\mathrm{m} \varepsilon$ \\
\hline Mayor & meə & 'mejo \\
\hline Court, caught & kot & kot \\
\hline Cut & $k \Lambda t$ & kot \\
\hline Faithful & fer $\theta f l$ & fetful \\
\hline Fateful & feitfl & fetful \\
\hline Potable & 'pptəbl & 'potabul \\
\hline Portable & 'potəbl & 'potabul \\
\hline Stiffen & 'stIfn & 'stifen \\
\hline Stephen & 'stivn & 'stifen \\
\hline
\end{tabular}




\section{Conclusions}

This study has compared consonants and vowels in RP and Cameroon English as spoken by highly educated people and has shown that these two varieties share a number of features. Where they differ, it is observed that the dominant factor underlying the differences is spelling pronunciation, as most words are pronounced the way they are spelt. Long and short vowels are neutralised and digraphs are usually articulated fully, causing many RP monophthongs to surface as diphthongs. Voicing of some segments in medial or final position in some words is not always observed, and this causes most voiced consonants to be replaced by their voiceless counterparts. These features combine to yield a variety which is intelligible with RP though being different from it. Characteristically, silent letters are articulated, the syllabic structure of words is shortened or lengthened, new homophones are created while known ones are pronounced differently. Needless to say, this way of speaking has been transmitted, over the years, from teachers to students and from media practitioners to the general public. Expectedly, similar features are observed in other places where English has been transported in the course of history.

\section{References}

Cameroon GCE Board (General Certificate of Education Board). (1997). Regulations and syllabuses for general education subjects. Victoria, Cameroon: Presbook Press.

Chomsky, N., \& Halle, M. (1968). The sound patterns of English (SPE). New York: Harper and Row.

Kouega, J. P. (1999a). Forty years of official bilingualism in Cameroon. English Today, 15(4), 38-43.

Kouega, J. P. (1999b). Some major speech traits of Cameroon media news in English. English Studies, 80(6), 540-555.

Kouega, J. P. (2007a). The language situation in Cameroon. CILP (Current Issues in Language Planning), 1-94

Kouega, J. P. (2007b). A dictionary of Cameroon English usage. Berne, Germany: Peter Lang.

Kouega, J. P. (2008). Bilingualism at tertiary level education in Cameroon: The case of the University of Yaounde II (Soa). Retrieved from http://www.isb6.org/static/proceedings/ kouega.pdf

Mbangwana, P. N. (1987). Some characteristics of sound patterns of Cameroon standard English. Multilingua, 64, 411-424.

MINEDUC (Ministère de l'Education Nationale) (Ministry of Education). (2000). National syllabuses for English-speaking primary schools in Cameroon. Yaounde: Imprimerie Saint John.

MINEDUC. (2001). Programmes officiels de l'enseignement primaire (Niveaux I, II et III) (Official syllabi for primary education (Levels I, II, and III)). Yaounde, Cameroon: Imprimerie Saint John.

O'Connor, J. D. (1973). Phonetics. Hamondsworth: Penguin.

Simo Bobda, A. (1994). Aspects of Cameroon English phonology. Bern: Peter Lang. 